\title{
EMPOWERMENT IN THE OPEN INNOVATION CONCEPT
}

\author{
PACHURA ANETA
}

\begin{abstract}
A B S T R A C T
The aim of this study is an attempt to interpret the concept of "empowerment" in the perspective of open innovation issues. The text consists of a brief introduction, four sections, and summary. The main background of the research is related to the importance of the social reality of the organisation to evolving paradigms of innovation. In the face of globalization challenges, the innovation management could be interpreted as a specific system based on interdisciplinary analysis of an organisation's social potential.

The methodology involves desk research and theoretical deliberations. As the results, this study distinguished attributes and role of empowerment in the social development process. The possibilities of an adoption of this concept to management in the open innovation context provide the theoretical contribution.
\end{abstract}

KEY WORDS

empowerment, management, open innovation, organisation

DOI: 10.1515/emj-2016-0022
Corresponding author:

Pachura Aneta

Faculty of Management Czestochowa University of Technology

e-mail: anetapachura@o2.pl

\section{INTRODUCTION}

The primary objective of this article is to make reflections on the significance of empowerment in the face of changing innovation paradigms based on the approach of open innovation systems. The first part takes the issue of social context in organisations up against the management process, the further second section focuses on epistemological foundations of empowerment, and the next part deals with the open innovation approach. The closing fourth section concentrates on propositions to implement empowerment in the range of open innovation environments.

In general, the theory of management studies and the dynamic network of social relationships reflect the picture of a modern organisation. The foundation of an organisational structure is a social network with the following attributes (Krannich \& Sworowska, 2009, p. 53):

- increasing subjectivity of a human being,

- increasing awareness of cooperation in a network of relations of social links,

- awareness of co-creation, impact and agency in the area of network relations,

- high level of trust in knowledge teams and network structures,

- high ethical standards in knowledge teams and network structures.

Building a strong internal social potential in a system of complex network relations leads to the 
search for new directions that could strengthen this potential. In this area, an interesting concept of strengthening social potential is „empowerment”.

The methodology applied in this article is based on a systematic review of the existing knowledge in the field. Deductive reasoning was the basic logic of investigation presented in this paper. Theoretical frameworks have been determined, especially around the social context of an organisation and the open innovations as a binding model of organisational practice. This theoretical analysis is interdisciplinary in nature and leads to systematizations, generalizations, and syntheses. evolution of the concept of a social human being gave rise to further intensification of the level of selfrealisation and co-participation, shaping, thus, an "active" attitude in the work environment (Kożuch, 2011, p. 162).

Attention directed to a human being concentrates not only around recognising his/her subjectivity or primacy. Creation of favourable organisational climate and organisational awareness in the context of the development and use of social potential also refer to such issues as formalisation and bureaucratisation of structures, style of management, flow of information, knowledge, skills and experience, dynamics of the environment, etc. The holistic

Tab. 1. Place of a human being in the new management paradigm

\begin{tabular}{|c|c|}
\hline $\begin{array}{l}\text { OBSERVATION AND } \\
\text { DECISION-MAKING } \\
\text { PERSPECTIVES } \\
\end{array}$ & SOCIAL CONTEXT IN THE NEW MANAGEMENT PARADIGM - SELECTED CHARACTERISTICS \\
\hline Organisation & $\begin{array}{l}\text { - } \quad \text { fulfilment of responsibilities in the environment of friendly organisational relations, } \\
-\quad \text { respecting a human being in the environment of friendly organisational relations, } \\
-\quad \text { satisfaction of individual needs, etc. in the environment of friendly organisational } \\
\text { relations, } \\
\text { - } \quad \text { cooperation, trust and freedom, } \\
\text { common values }\end{array}$ \\
\hline Knowledge & $\begin{array}{ll}- & \text { learning, improving qualifications, } \\
- & \text { improving skills, gaining experience, } \\
- & \text { creativity, entrepreneurship, } \\
- & \text { pro-innovativeness, } \\
- & \text { decision-making, responsibility, } \\
- & \text { activity and flexibility }\end{array}$ \\
\hline Safety & $\begin{array}{ll}\text { - } & \text { vigilance, assertiveness, } \\
- & \text { prevention, } \\
- & \text { dynamism, } \\
- & \text { defensiveness }\end{array}$ \\
\hline
\end{tabular}

Source: own study adjustment based on (Domański, Kotarba \& Krupa, 2014, pp. 36-37, 39).

\section{ORGANISATION AS AN AREA FOR RECOGNITION OF EMPOWERMENT}

The humanistic approach in management studies identifies the need to reorient the philosophy of an organisation in the direction of accepting the subjective role of a human being and creating a friendly organisational environment. Thus, a strong emphasis is placed on the issues of human experience and fate in organisations (Kociatkiewicz \& Kostera, 2013, pp. 9-19). This perspective closely corresponds with the concept of a social human being in the light of the development of behavioural approach (Kożuch, 2011, p. 162). It is accepted that „interpersonal relations are a very strong source of motivation for the behaviour of humans, who strive for their value being recognised in their work environment, being guided not only by material considerations, but also feelings and emotions" (Kożuch, 2011, p. 162). The approach in the new paradigm of management studies allows looking for properties of the social potential of an organisation (Tab. 1).

The identified properties of social potential incite the reflection on the issues of managing people in an organisation. This issue seems particularly important especially in the context of managing people with high potential, talents, knowledge workers or trust strengthening. Given these properties, social potential often requires looking for an unconventional approach by building a free, flexible and dynamic organisational architecture. Moreover, it entails the need to improve the concept of leadership in the direction of strengthening an employee subjectivity and agency.

Analysis of selected interpretative bases of leadership leads to a view that this concept is most often associated with the issues of power, responsibility, dominance, abilities, selection of a leadership style, emergence of leadership and 
shaping of leadership qualities, attitudes and behaviours (Mrówka, 2005, pp. 16-17). Thus, leadership can be perceived in terms of relations, process, abilities/skills, qualities or impact (Aftyka, 2014, p. 114). In this context, the concept of empowerment may represent a very interesting proposal of a detailed description of the issues of leadership in a modern organisation.

\section{EPISTEMOLOGICAL FOUNDATIONS OF EMPOWERMENT}

Leadership in an organisation in a broad sense can be examined at four levels: education, purposefulness, practical implementation of a strategy and achievement of efficiency/effectiveness of the leadership process (Aftyka, 2014, p. 115). Empowerment is a part of the multi-faceted perception of leadership, where knowledge, qualifications, abilities, innovativeness, good business practices as well as openness, activity and flexibility are regarded as key attributes of a modern organisation.

The idea of empowerment appeared in the 80s. Academic literature indicates that „empowerment is both a value orientation for working in the community and a theoretical model for understanding the process and consequences of efforts to exert control and influence over decisions that affect one's life, organisational functioning, and the quality of community life" (Zimmerman, 2000). Based on management studies, the fundament of the characterisation of social potential, organisational culture and system architecture of an organisation rests on the search for key properties of this concept (Tab. 2). Properties for the description of social potential focus in the first place on individual characteristics of an individual, presented attitude, as well as how an organisation operates. Thus, the following properties are named, among other things: creativity, unconventionality, involvement, responsibility, honesty, autonomy, freedom and discretion of action. The identified properties of social potential represent a valuable attribute of a modern organisation that determines its functioning in the space of social relations. However, the social potential in this dimension requires an organisational culture that is focused on acceptance of dissimilarity and diversity, development of cooperation, free exchange of knowledge, trust as well as the permission to make mistakes and the proactive use of information feeds. Meanwhile, in the light of the analysis of the foundations of empowerment, the system architecture of an organisation is mainly constituted by openness, the flexibility of structures and minimisation of bureaucracy.

The concept of empowerment is based on the subjectivity of an employee, his/her self-awareness,

Tab. 2. Empowerment - epistemological perspective

\begin{tabular}{|c|c|c|}
\hline ITEM & AUTHOR & SELECTED CHARACTERISTICS OF EMPOWERMENT \\
\hline 1. & $\begin{array}{l}\text { R. Zemke \& D. Schaaf } \\
\text { (1989) }\end{array}$ & $\begin{array}{ll}\text { - } & \text { acceptance of involvement and initiation of activities } \\
- & \text { reinforcement of creative behaviours } \\
\text { - } & \text { inspiration for fantasy }\end{array}$ \\
\hline 2. & $\begin{array}{l}\text { D. E. Bowen \& E. E. Lawler } \\
\text { (1992) }\end{array}$ & $\begin{array}{ll}- & \text { flows of information and knowledge streams } \\
- & \text { power distribution } \\
-\quad & \text { information, knowledge and power sharing as the basis for deci- } \\
\text { - } & \text { sion-making } \\
\text { rewarding bonuses for effectiveness }\end{array}$ \\
\hline 3. & $\begin{array}{l}\text { S. H. Appelbaum \& K. Honeggar } \\
\text { (1998) }\end{array}$ & $\begin{array}{ll}- & \text { freedom to initiate activities } \\
- & \text { the feeling of the need to get involved } \\
- & \text { the possibility of exceeding the standard scope of responsibilities }\end{array}$ \\
\hline 4. & $\begin{array}{l}\text { M. Bratnicki } \\
(2000)\end{array}$ & $\begin{array}{ll}- & \text { complexity and multidimensionality } \\
- & \text { multi-subject scope } \\
- & \text { dynamism and continuity } \\
- & \text { integration of organisational and psychological spheres } \\
- & \text { cause and effect relationship between the effectiveness of activity } \\
\text { and the level of an individual's empowerment } & \text { active communication } \\
-\quad & \text { intensification of the level of autonomy and responsibility }\end{array}$ \\
\hline 5. & $\begin{array}{l}\text { M. Bugdol } \\
(2006)\end{array}$ & $\begin{array}{l}\text { - } \begin{array}{l}\text { integration of organisational, psychological, pedagogical } \\
\text { and social spheres }\end{array} \\
\text { - } \quad \text { dynamism and continuity } \\
\text { - } \quad \text { change of organisational roles } \\
-\quad \text { the capability of systemic thinking } \\
\text { - identification with strategic objectives of an organisation }\end{array}$ \\
\hline
\end{tabular}

Source: own study adjustment based on (Brajer-Marczak, 2013, pp. 23-35; Bratnicki, 2000, pp. 22-25; Moczydłowska, 2014, pp. 71-78). 
self-esteem and organisational agency. Academic literature defines empowerment as „a construct that links individual strengths and competencies, natural helping system, and proactive behaviours to social policy and social change" (Perkins \& Zimmerman, 1995, pp. 569-579). It means that empowerment enriches the set of traditional managerial techniques. In simple terms, it is the expansion of the classical view of management from the perspective of a delegation of powers/ responsibilities and participation of employees. Some authors describe „empowerment” as a specific organisational strategy containing hierarchical goals such as: vision creation, communication channels, developing strong social relationships or building social networks (Erstad, 1997, p. 326; Nixon, 1994, pp. 14-24).

The strength of empowerment is based on the subjectivity of every employee and favourable organisational climate, understood in terms of organisational culture and system architecture of an organisation. It seems obvious that there should be a shift from authoritative and formal models towards the development of democracy and liberalism for increased participation and involvement. However, in the area of social relations, dynamic and open network environment is a prospect for effective leadership in an organisation and for exercising power. Moving around such an environment and taking advantage of its attributes requires organisational awareness of the need for unconventional behaviour and attitudes in the sphere of stimulating involvement, free cooperation, active exchange of information, processes of mutual learning, etc.

Academic literature proposes the description of the issues of leadership in the area of innovativeness using a detailed characterisation (Kruk, 2016, p. 412):

- of the profile of the leader, his/her characteristics, competencies and conditions,

- relations of the leader with the entities of an innovation environment (internal and external environment).

Most often it is assumed that leadership is a dynamic process and "leadership is not a function of level or position" (Prewitt, Weil \& McClure, 2011, p. 13). As noted by Raišienè, „the modern conception of leadership emphasises not only the leader as an individual but also the group he influences and joint results" (Raišienè, 2014, p. 180). The issue of leadership is also considered not as an individual action but a collective social process (Bolden, 2011, p. 251). It seems that the proposed perspective of the analysis of leadership may also refer to the concept of empowerment. However, in the light of the interpretation of this concept, the subject structure is indicated, i.e. empowering subject and empowered subject, which is one of the necessary conditions for capturing the essence of empowerment (KanafaChmielewska, 2012, p. 138). Meanwhile, from the perspective of the environment of the network of social relations, in which innovativeness is currently set, it seems highly valuable to conduct an analysis at the level of characterisation of all entities co-participating in the process of development and implementation of innovations.

An important part of the practical implementation of the idea of empowerment is the issue of the assessment of organisational empowerment. One approach to the assessment of organisational empowerment is a diagnosis on the following key criteria: dynamic structural framework, control of workplace decisions, and fluidity in information sharing (Moczydłowska, 2015, pp. 82-83). Generalizing, it can be assumed that the measurement of empowerment requires an analysis of many areas of an organisation related to knowledge of managerial staff and groups of employees, organisational culture, management style and trust, organisation's ability to change, access to the information, etc. It seems that the issue of the empowerment measurement methodology requires a complex approach and should be developed in terms of theoretical and practical activities.

\section{OPEN INNOVATION IN THE DIRECTION OF A NEW VIEW OF THE INTERNAL SOCIAL POTENTIAL OF AN ORGANISATION}

In „Innovation paradigm shift from a closed to an open model" (Chesbrough \& Crowther, 2006, p. 229) and as noted by Conger \& Kanungo, empowerment is the "construct used by theorists to explain organisational effectiveness" (Conger \& Kanungo, 1988, p. 471). The concept of open innovation reflects the holistic approach on the issues of development and implementation of innovations. Its essence is a new view on the 
innovative potential, in particular with reference to possibilities of gaining it and using in an own innovation strategy (Odrobina, 2014, p. 461). The development and implementation of innovations in an open environment takes place in a network of relations. These relations reflect the interactions existing in the network that can take place at the level of cooperation, communication, conflict, etc. (Bogdanienko, 2016, p. 25). It is, however, worth bearing in mind that these interactions take place in the space of social relations. The space of social relations is very complex and dynamic. The foundation of its development is the need and willingness to communicate. Communication is regarded as a factor in the development and maintenance of relations, which determine coexistence of organisations (Janowska, 2016, p. 252).

The general theory of innovations emphasises knowledge, development of technology, research and development, information and communication technologies, participants of innovation process as well as institutional, technological, social and other factors (Sundbo, 2001, p. 72). As noted by Sisodiya et al., „an open innovation is the sustained and systematic practice of engaging in the search for and then integrating new product inputs from sources that cross firm boundaries and, often, technology boundaries" (Sisodiya et al., 2013, p. 2). In the approach open to innovation, various forms of cooperation and commercial transactions in the area of knowledge and technology are used (Odrobina, 2014, p. 462). In this respect, active and free cooperation between innovation entities is of particular importance. Moreover, in a mixed open innovation there is a two-way flow of knowledge and information, a network has a decentralised form, and "every participant has equal access to the effects of the cooperation" (Sopińska, 2013, p. 291). Thus, it seems that social potential, which is dynamic and open to cooperation, will significantly support innovation.

Academic literature shows that in open innovation, the power distance is shortened and cross-organisational task teams are formed (Olko, 2009 , p. 164). Thus, open innovation not only expands the subject structure of innovations, creating the climate for active engagement of the external environment, or modifies the form of this engagement in the direction of cooperation, codecision and co-responsibility.

At the basis of the interpretation of the importance of internal social potential for the development and implementation of innovation is the intellectual and creative potential of employees and knowledge resources (Rynkiewicz, 2014, p. 129). From the perspective of open innovation, the following attributes become highly desired: creativity, flexibility, freedom, dynamics, unconventionality, diversity and responsibility. In the light of these characteristics, the issues of managing, leading and participation go beyond the classical standards. They require an innovative approach to the internal social potential of an organisation, aimed at strengthening the potential of a human being. In this respect, the following needs are indicated, among other things, in the area of management (Olko, 2009, pp. 164-165):

- identification of networks, including social and informal networks, for processes of mutual diffusion of knowledge,

- allocation of knowledge employees in networks,

- the motivation of employees and coordination of their actions in knowledge processes,

- departure from classical prescriptive decisions and control measures,

- building authority on the ability to create and stimulate cross-organisational network relations,

- the increase in mutual trust between participants of the network as a result of knowledge sharing. Thus, an employee's subjectivity and the organisational agency are regarded as the foundation of the development of a new philosophy of an organisation oriented towards open innovations.

\section{Perspective on IMPLEMENTATION OF EMPOWERMENT IN THE ENVIRONMENT OF OPEN INNOVATION}

In open innovation, new knowledge is a highly valuable resource. The description of an organisational environment that is conducive to the creation of new knowledge includes creativity and originality. The development of these qualities more frequently results from recognition of autonomy, freedom, and discretion of activity at the level of social network relationships. Empowerment strongly highlights subjectivity of a human being. However, as a result 
of the development of self-awareness, self-esteem, and agency, it complementarily strengthens the importance of an employee for an organisation. Empowerment in the direction of conscious and active co-participation in processes of knowledge creation, acquisition, and diffusion, results in increased involvement, responsibility, self-control and self-discipline. Often, it also leads to searching for new mechanisms of knowledge management. In this respect, one can point to the so-called communities of practice, which are characterised by such attributes as trust, factual knowledge, freedom of participation, mutual verification, cooperation, exchange of information, and experience (Mierzejewska, 2005, pp. 53-54).

The practical implication of the principles of empowerment will require a reorientation of the process of leadership in the direction of the democratic and liberal form. Leadership in this respect will mean in the first place a reasonable partnership, developed in structures of informal network relations based on mutual trust. Classical participation is replaced by the focus on cooperation, agency and co-responsibility.

In the environment of open innovation and network of social relations, the concept of empowerment strongly corresponds with the issues of talent management. Talent as a key attribute of an employee is subject to management processes in the context of creating an organisational climate that is conducive to self-development and self-realisation. It is, however, worth noting that strengthening individual social potential at the level of talent essentially refers to the sphere of organisational culture and system architecture of an organisation. Thus, it firstly requires the acceptance of otherness, diversity and feeling of trust as well as openness and flexibility of structures.

Undoubtedly, the issues of managing talents in the area of practical application of empowerment in open innovation strongly correspond with the issue of creativity and involvement. It is especially important in this respect to create an environment for individual involvement, perseverance and activity in work, motivation as well as new networks and structures of knowledge dissemination, formulation of hypotheses, etc. (Jabłoński, 2015, p. 38). It seems, thus, that the proposed complementary approach to the issues of talents that takes into account individual and organisational levels, is a chance for strengthening the force of social potential. However, it is worth stressing at this point that in the face of the development of innovation in an open system, it seems very important to support employees with higher than average talents and skills. An argument for this thesis can be the need of innovation and originality as well as the necessity of developing unique competencies. It is, however, increasingly stressed that „currently, talent development programmes do not mention only the best employees, but they are designed to ensure the development of all the employees of an organisation defined as its talents" (Kamińska, 2016, p. 308). The adopted cognitive context serves the implementation of empowerment for the development of the internal social potential of an organisation in open innovation.

\section{CONCLUSIONS}

Analysis of the issues of open innovation shows the need for a new view of the internal social potential of an organisation. In the environment of complex network relations, we observe interdisciplinarity and holistic approach to innovation, free flows of knowledge and experience, active cooperation of network participants as a result of free involvement, co-responsibility, and mutual trust. Moving around the space of open innovation increasingly requires a restructuring of classical organisational roles. Prescriptive and demanding leadership is replaced by the partnership. An employee's subjectivity and agency underlie discussions on the improvement of management of social potential.

The epistemological discussion presented in this paper about the possibility of practical application of empowerment in open innovation prompts the following thoughts:

- the network of social relations changes the perspective on the performance of management processes in the direction of open, free, and dynamic systems,

- the concept of empowerment matches the characterisation of social potential, organisational culture and system architecture of an organisation,

- empowerment leads to the strengthening of internal social potential in an environment of complex and dynamic network relations.

These suggest ideas for a further detailed research focused on empirical exploration. However, researchers need to be aware of many limitations in this area linked with the social dynamics in organisations and the society as well as the rapidly growing importance of technologies, especially ICT. 


\section{LITERATURE}

Aftyka, W. (2014). Przywództwo w organizacji [Leadership in an organization]. In W. Harasim (Ed.), Człowiek i organizacja - dylematy wspótczesnego zarządzania [Human and organization - dilemmas of contemporary management], (pp. 111-121). Warszawa, Poland: Wydawnictwo Wyższej Szkoły Promocji.

Bogdanienko, J. (2016). Zarządzanie w spiralnie zapętlonej sieci - refleksje nad relacjami międzyorganizacyjnymi [Management in a Spirally Looped Network - Deliberations on Inter-organizational Relations]. Przegląd Organizacji, 2, 21-29.

Bolden, R. (2011). Distributed leadership in organizations: A Review of theory and research. International Journal of Management Reviews, 13, 251-269. doi: 10.1111/j.1468-2370.2011.00306.x

Brajer-Marczak, R. (2013). Empowerment pracowników $\mathrm{w}$ przedsiębiorstwie zorientowanym $\mathrm{w}$ zarządzaniu na procesy [The empowerment of workers in processoriented enterprise]. Zeszyty Naukowe Wyższej Szkoły Bankowej we Wrocławiu, 36(4), 23-35.

Bratnicki, M. (2000). Podstawy współczesnego myślenia o zarzadzaniu [The basis of contemporary thinking on management]. Dąbrowa Górnicza: Wydawnictwo Wyższej Szkoły Biznesu w Dąbrowie Górniczej.

Chesbrough, H. W., \& Crowther, A. K. (2006). Beyond high tech: Early adopters of open innovation in other industries. R\&D Management, 36(3), 229-236.

Conger J. A., \& Kanungo R. N. (1988). The Empowerment Process: Integrating Theory and Practice. Academy of Management Review, 13(3), 471-482.

Domański, J., Kotarba, W., \& Krupa, T. (2014). W pryzmatach zarządzania [The prisms of management]. Marketing i Rynek, 5, 33-40.

Erstad, M. (1997). Empowerment and organizational change. International Journal of Contemporary Hospitality Management, 9(73), 325-333.

Jabłoński, M. (2015). Istota, funkcje i praktyki zarządzania talentami pracowniczymi [The Essence, Functions, and Practices of Talent Management]. Zeszyty Naukowe Wyższej Szkoły Bankowej w Poznaniu, 60(3), 31-48.

Janowska, J. (2016). Cztery wymiary komunikowania się $\mathrm{w}$ organizacji [Four Displays of Communication within a Company]. Marketing i Rynek, 3, 252-262.

Kamińska, B. (2016). Zarządzanie talentami jako koncepcja zarządzania kapitałem ludzkim w MSP [Talent Management as a Concept of Human Resources Management in SME's]. Marketing i Rynek, 3, 305314.

Kanafa-Chmielewska, D. (2012). Umacnianie (Empowerment) - pojęcie i istota [Empowerment chosen issues]. Współczesne Zarządzanie, 1, 130-140.
Kociatkiewicz, J., \& Kostera, M. (2013). Zarządzanie humanistyczne. Zarys problemu [Humanistic management: Agenda outline]. Problemy Zarzadzania, 11(4), 9-19.

Kożuch, B. (2011). Humanizm organizacyjny w koncepcjach zarządzania publicznego [Organizational Humanism in Concepts of Public Management]. In S. Banaszak, \& K. Doktór (Eds.), Socjologiczne, pedagogiczne $i$ psychologiczne problemy organizacji $i$ zarządzania [Sociological, pedagogical and psychological problems of organization and management], (pp. 161-169). Poznań, Poland: Wydawnictwo Wyższej Szkoły Komunikacji i Zarządzania.

Krannich, M., \& Sworowska, A. (2009). W kierunku nowego paradygmatu zarządzania - z prac Katedry Podstaw Zarządzania i Marketingu [Towards a new paradigm in management - The works of the Department of Fundamentals of Management and Marketing]. In M. Nowicka-Skowron (Ed.), Zarzadzanie sieciami współdziałania $w$ procesie budowy innowacyjnej organizacji $i$ regionu [Management of networks of cooperation in the process of creation an innovative organization and region], (pp. 51-57). Częstochowa, Poland: Wydawnictwo Wydziału Zarządzania Politechniki Częstochowskiej.

Kruk, M. (2016). Przywództwo w organizacji a jej innowacyjność [Leadership in Organization and its Innovativeness]. Marketing i Rynek, 3, 411-420.

Mierzejewska, B. (2005). Społeczności praktyków. Efektywne tworzenie i wykorzystywanie wiedzy w organizacji [Communities of practice. The effective creating and using knowledge in a company]. E-mentor, 1(8), 52-57.

Moczydłowska, J. M. (2015). Empowerment - a new look at activaiting human potential in an organization. Measures of empowerment. In K. Stankiewicz (Ed.), Contemporary Issues and Challenges in Human Resource Management, (pp. 78-88). Gdańsk, Poland: Politechnika Gdańska.

Moczydłowska, M. (2014). Empowerment - nowe spojrzenie na aktywowanie potencjału ludzkiego organizacji [Empowerment - a new look for the activation of human potential in the organization]. Zeszyty Naukowe Wyższej Szkoły HUMANITAS, 1, 71-78.

Mrówka, R. (2005). Przywództwo w otoczeniu burzliwym [Leadership in turbulent environment]. E-mentor, 1(8), 16-19.

Nixon, B. (1994). Developing an empowering culture in organizations. Empowerment in Organizations, 2(1), 14-24.

Odrobina, A. (2014). Otwarta innowacja a internacjonalizacja działalności badawczorozwojowej współczesnych przedsiębiorstw [The open innovation and the internationalization of research and development activity of contemporary enterprises]. International Business and Global Economy, 33, 459-469. 
Olko, S. (2009). Dyfuzja wiedzy w procesie otwartej innowacji [The diffusion of knowledge in the open innovation process]. In M. Nowicka-Skowron (Ed.), Zarządzanie sieciami współdziałania $w$ procesie budowy innowacyjnej organizacji i regionu [Management of networks of cooperation in the process of creation an innovative organization and region], (pp. 157-167). Częstochowa, Poland: Wydawnictwo Wydziału Zarządzania Politechniki Częstochowskiej.

Perkins, D. D., \& Zimmerman, M. A. (1995). Empowerment theory, research, and application. American Journal of Community Psychology, 23(5), 569-579.

Prewitt, J., Weil, R., \& McClure, A. (2011). Developing Leadership in Global and Multicultural Organizations. International Journal of Business and Social Science, 2(13), 13-20.

Raišienè, A. (2014). Leadership and managerial competences in a contemporary organization from the standpoint of Business Executives. Economics and Sociology, 7(3), 179-193. doi: 10.14254/2071789X.2014/7-3/14

Rynkiewicz, D. (2014). Rola pokolenia Y w tworzeniu innowacji otwartych [Role of the Y Generation in Creating Open Innovations]. Edukacja Ekonomistów i Menedżerów, 4(34), 122-137.

Sisodiya, S. R. et al. (2013). Inbound open innovation for enhanced performance: Enablers and opportunities. Industrial Marketing Management, 42(5), 836-849. doi: 10.1016/j.indmarman.2013.02.018

Sopińska, A. (2013). Otwarte innowacje bazujące na mądrości „tłumu” - podstawa sukcesu współczesnego przedsiębiorstwa [Open innovations based on the wisdom of "crowds" - the basis of success of a modern enterprise]. Zarzadzanie i Finanse, 4(1), 288-302.

Sundbo, J. (2001). The Strategic Management of Innovation. A Sociological and Economic Theory. Bodmin, Great Britain: MPG Books Ltd.

Zimmerman, M. A. (2000). Empowerment Theory. Psychological, Organizational and Community Levels of Analysis. In J. Rappaport, \& E. Seidman (Eds.), Handbook of Community Psychology, (pp. 4363). New York, USA: Springer. 